Professional paper

\title{
TOURISTS' PERCEPTION ON THE IMAGE OF KANJIZA AS A TOURIST DESTINATION
}

\section{PREDSTAVA TURISTA O KANJIŽI KAO TURISTIČKOJ DESTINACIJI}

Nataša Mitrović, Msc Manager in Tourism

Marketing Manager at Tourist Organization of Kanjiza Municipality

Address 24420 Kanjiza, Ribarski trg 2/3

Phone: $\quad+381642754648$

E-mail: $\quad$ mitrovic.natasa@gmail.com 


\title{
TOURISTS' PERCEPTION ON THE IMAGE OF KANJIZA AS A TOURIST DESTINATION
}

\author{
PREDSTAVA TURISTA O KANJIŽI KAO TURISTIČKOJ \\ DESTINACIJI
}

\begin{abstract}
The tourism of Kanjiza is commonly based on its health and spa offer, while sport, recreation and events may be added as supplementary. Considering that in the year of 2005 tourism became one of the priorities in the Development Strategy of Kanjiza Municipality, a more intense promotion of its tourist potentials has been conducted on the tourism market.

The objective of this paper is to perceive, using the method of opinion poll, the effects of promotional activities on tourists, in order to realize what kind of image among its visitors Kanjiza has as a tourist destination. To begin a research of this kind, first of all, the term of the image of tourist destination is needs to be perceived, along with the theoretical and methodological framework of the usage of the opinion poll, as a specific instrument of the market research. It is also important to define the advantages and disadvantages of the different type of questions, which are usually a part of the opinion poll. The research of this kind belongs to the field of marketing research and it is important from the angle of reviewing the previous results and making conclusions in order to improve marketing activities to reach a better position on the market of tourism and keep it.

The structure of the respondents varies by gender and age group, while domestic tourists dominate among them. The major findings of the research are related to the data analysis obtained from the respondents, are the basic view of the image of Kanjiza as a tourist destination, and recommendation were given about further marketing activities. The seeking answers are about the questions of ideas associatiated with Kanjiza, sources of information, purposes of visiting, rating of the elements of the promotional activities which have impact on the quality of the whole tourist destination, the accuracy and truthfulness of promotional activities and suggestions for the improvement of the promotional activities.

The "Spa of Kanjiza" is most frequently associated with Kanjiza and the most common purpose of visiting this town, although other amenities are also related to Kanjiza as a tourist destination. One of the results of this research which indicates that informing about Kanjiza via the Internet is significant, emphasizes that the subjects of the local tourism industry (the Special Hospital for Medical Rehabilitation "Banja Kanjiza", private hotels and private accommodation owners, the local tourist organization, even the local government) need to approach the development of the so-called e-marketing seriously, which includes advertising, interaction with potential tourists and distribution of the products via the Internet.

The quality of the tourist products and the whole tourist destination is one of the conditions of the long-term success on the tourism market, where instead of low prices, value for money has become the main request of the subjects of the travel demand. The image of the tourist destination is being formed not only during the stay, but also upon the information obtained in the tourists' hometown and the memories about the destination after their holiday. Particular elements of the promotion could be directly related to the quality of the tourist destination and rated, using scales, by which the visitors can express their satisfaction with them.

Some of the important characteristics are the accuracy and truthfulness of the data used for promotion, as well. This research revealed positive results related to this matter.

One of the most important advantages of the open-ended questions in opinion polls is that they do not suggest any answers to respondents; therefore the researchers could reveal unexpected details about their opinion and points of view. The respondents could give their recommendation about the useful characteristics of the tourism offer in Kanjiza, which could be used in the promotional activities: the politeness and the professionalism of the staff, the cleanliness and the arrangement of the environment, Hungarian folklore and cuisine, famous persons, etc... These suggestions are important in case that these characteristics used for promotion, which are interesting to the guests in Kanjiza, might attract potential tourists with the same or similar preferences.
\end{abstract}

Keywords: Kanjiza, tourist destination image, marketing research 


\begin{abstract}
:
Turizam Kanjiže je prvenstveno zasnovan na ponudi zdravstvenog turizma, a kao dodatni se mogu navesti i sportsko-rekreativni i manifestacioni sadržaji. S obzirom na to da je 2005. godine turizam u Strategiji razvoja opštine Kanjiža prepoznat kao prioritetna delatnost, pristupilo se i intenzivnijoj promociji njenih turističkih potencijala na tržištu.

Ovo istraživanje ima za cilj da sagleda predstavu (imidž) Kanjiže kao turističke destinacije među posetiocima pomoću anketnog istraživanja. Da bi se pristupilo istraživanju ove vrste najpre je potrebno sagledati pojam imidža turističke destinacije, kao i teorijske i metodološke okvire korišćenja anketnog upitnika, kao svojevrsnog instrumenta istraživanja tržišta. Takođe je važno upoznati se sa prednostima i manama pojedinih tipova pitanja u anketnom upitniku. Istraživanja o predstavi turista o pojedinim turističkim destinacijama pripadaju oblasti marketinga i istraživanja tržišta, a značajna su sa aspekta sagledavanja dosadašnjih rezultata $\mathrm{i}$ izvođenja zaključaka radi unapređenja marketinških aktivnosti, kako bi se poboljšalo $i$ zadržalo mesto na turističkom tržištu.

Struktura ispitanika je raznovrsna prema polu i starosnoj grupi, a dominiraju domaći turisti. Glavni rezultati istraživanja se odnose na analizu podataka dobijenih iz odgovora ispitanika na osnovu kojih se sagledava imidž Kanjiže kao turističke destinacije, a daju se i preporuke o daljim pravcima marketinškog delovanja. Pitanja na koja se traže odgovori su vezana za prve asocijacije posetilaca, izvore informisanja o Kanjiži, motive posete, ocenu pojedinih elemenata turističke promocije koji utiču na kvalitet turističke destinacije u celini, istinitost propagande i predloge za poboljšanje promotivnih aktivnosti.

Najčešća asocijacija na Kanjižu, kao i dominirajući motiv posete vezani su za „Banju Kanjižu“, ali su primetni i ostali sadržaji koje su ispitanici vezali za Kanjižu kao turističku destinaciju. Jedan od rezultata anketnog istraživanja otkriva činjenicu da je značajan broj onih koji su se o Kanjiži informisali putem Interneta, što ističe potrebu ozbiljnog pristupa svih nosilaca turističke ponude na destinaciji (Specijalne bolnice „Banja Kanjiža“, privatnih hotela, vlasnika privatnih soba za iznajmljivanje, lokalne turističke organizacije, pa čak i lokalne saomouprave) razvoju tzv. e-marketinga. On podrazumeva oglašavanje, interakciju sa potencijalnim turistima i distribuciju turističkih proizvoda putem Interneta.

Kvalitet turističkog proizvoda na nivou cele destinacije je jedan od uslova dugoročnog opstanka na turističkom tržištu, gde je umesto pristupačnih cena, glavni zahtev tražnje postao dobijanje prave vrednosti za novac. Predstava turista o destinaciji vezana je ne samo za sam boravak, već i za informacije o destinaciji pre i posle putovanja. Pojedini elementi promocije direktno su vezani za kvalitatet turističke destinacije, a njihovo ocenjivanje se može izvršiti koristeći skale, pomoću kojih će posetioci izraziti svoje zadovoljstvo sa njima.

Kao bitne karakteristike se mogu navesti i istinitost $\mathrm{i}$ tačnost podataka koji se koriste prilikom preduzimanja promotivnih aktivnosti, pri čemu se na osnovu ovog istraživanja došlo do pozitivnih zaključaka o istinitosti i tačnosti propagande turističke ponude u Kanjiži.

Jedna od glavnih prednosti otvorenih pitanja u anketnim upitnicima je to što ne sugerišu odgovore ispitanicima, te istraživači mogu otkriti neočekivane podatke o stavovima i mišljenjima anketiranih. Tako su posetioci naveli svoje predloge o tome koje karakteristike Kanjiže se mogu iskoristiti u promotivne svrhe: ljubaznost i profesionalnost osoblja, čistoća i uređenost mesta, mađarski folklor i mađarska kuhinja, znamenite ličnosti, itd... Ovi predlozi su značajni jer ukoliko se navedene karakteristike, interesantne sa stanovišta već postojećih turista, iskoriste u promotivnim aktivnostima, mogu se privući potencijalni turisti sa istim ili sličnim preferencijama.
\end{abstract}

Ključne reči: Kanjiža, imidž turističke destinacije, istraživanje tržišta

\title{
INTRODUCTION
}

The development of tourism in Kanjiza began in 1913, when the first facilities were built in order to exploit the hot mineral water for bathing. Nowadays, the guests are mainly patients on rehabilitation, although the Spa offers some wellness and relaxation programs. Beside that, the municipality of Kanjiza has a great number of natural and cultural attractions, as well as sport and recreational facilities: the Tisa River, multiculturalism, cultural and sport events. Its location on the Hungarian border increases its chances for 
competitiveness on tourism market of the region - Kanjiza is called the "Northern Gate to Europe".

In the year of 2005 tourism was recognized as an industry of great potential and therefore became one of the priorities in the Development Strategy of Kanjiza Municipality. The Strategic Plan of Tourism Development was also defined and in the same year the Tourist Organization of Kanjiza Municipality was founded. One of the most important tasks of this organization is promoting Kanjiza as a tourist destination. The aim of this research was to perceive the effects of promotional activities on tourists and to realize what kind of image among its visitors Kanjiza has, as a tourist destination.

\section{OBJECTIVES AND METHODS OF THE SURVEY}

The term "image" generally refers to a complication of beliefs and impressions based on information processing from a variety of sources over time, that result in an internally accepted mental construction (Mackay J.K, 2005).

The method used to get information from the tourists about their perception on the image of Kanjiza as a tourist destination was interviewing by opinion poll. This method includes a series of actions, by which statements of people are aroused, collected and analyzed in order to get data about their behavior, opinion, preferences or interests for social, medical, economical or any other kind of research (Cerovic S, 2004).

The questions, which supposed to be answered after the analysis of this survey, are: Do visitors perceive Kanjiza as a tourist destination? Which factors influence tourists to travel to Kanjiza? Has their perception of Kanjiza changed after seeing and experiencing it during their stay?

A number of 78 visitors were chosen randomly between $5^{\text {th }}$ and $30^{\text {th }}$ of August, in the year of 2010 on various locations in Kanjiza: hotels "Aquapanon", "Lupus" and "Aquamarin", in the town's park, at the bank of the Tisa River. The tourists were filling in the questionnaires themselves or they were interviewed in Serbian, Hungarian or English language.

\begin{tabular}{|c|c|}
\hline Language & $\begin{array}{c}\text { Number of the filled } \\
\text { questionnaires }\end{array}$ \\
\hline Serbian & 62 \\
\hline Hungarian & 13 \\
\hline English & 3 \\
\hline In total & $\mathbf{7 8}$ \\
\hline
\end{tabular}

Table 1: The Number of Responded Questionnaires by Language 
A substantial majority of respondents were domestic tourist $-78.4 \%$. The questionnaire consists of 12 questions, which can be split into categories: close-ended (dichotomous questions, questions with multiple choices and ranking scale questions) and open-ended questions.

With closed-ended questions, the researcher provides a set of pre-determined response alternatives for the respondent to use when answering the question. With openended questions, respondents are free to devise their own unique answers to the questions posted. Providing a pre-determined set of responses is advisable when it is possible to anticipate the full range of possible responses and when these responses are relatively few in number. They are also easier to answer and reduce the time and effort needed to code responses for data entry and analysis, so they have become referable. The clearest advantage of open-ended questions is that they don't suggest the answers to the respondents and allow researchers to find out something unanticipated, but they on the other hand, suffer a lower response rate than closed-ended questions (Ruane M. J, 1998).

\section{STRUCTURE OF THE RESPONDENTS}

Just over half of the respondents belong to the age groups between 16 to 25 and 46 to 65 with $2 \%$ more male respondents than female. Also, the number of those who belong to the age group between 26 and 35 should not be neglected (20.25\%). These facts indicate a balanced structure of the respondents.

The tourists, who gave their opinion, origin from different countries, cities and towns. The majority of domestic tourists (2/3 of the respondents) were from Vojvodina (Novi Sad, Subotica, Kikinda, Temerin, Vrsac, Zmajevo, Nova Pazova, Ruma, Sremska Mitrovica, Sombor). Beside them, numerous are those who came from Belgrade and there is a limited number of respondents from other parts of Serbia (Valjevo, Kraljevo, Surdulica). Foreign tourists came mostly from the neighbour countries - Hungary (Budapest, Debrecen) and the Federation of Bosnia and Herzegovina (Ugljevik, Sarajevo, Trebinje) - and from Germany.

A significant percentage of the respondents had visited Kanjiza at least twice before - $47 \%$ and $20 \%$ of respondents had visited Kanjiza more than five times. This leads to a conclusion that the tourists who visit Kanjiza stay frequently, which can be marked as a positive result. It is much more efficient to keep the guests by good service and courtesy of 
staff than seek for a new potential guest by promotional activities and, of course, nothing can be as good promotion as a satisfied tourist.

Repeated visits of those who have visited before can also be caused by different type of events, such as international or domestic sporting events, festivals and exhibitions. Not only does event encourage people to visit but media provides an opportunity to promote the tourist destination.

\section{MAJOR FINDING OF THE SURVEY}

The Associations with Kanjiza. The aim of revealing what crosses the minds of tourists when they think about Kanjiza is directly connected to the subject matter of this research. Among the multiple answers were those, which are non-tourist associations, such as "producing bricks" which is also one of the characteristics of Kanjiza. The results are shown in the following graphic 1:

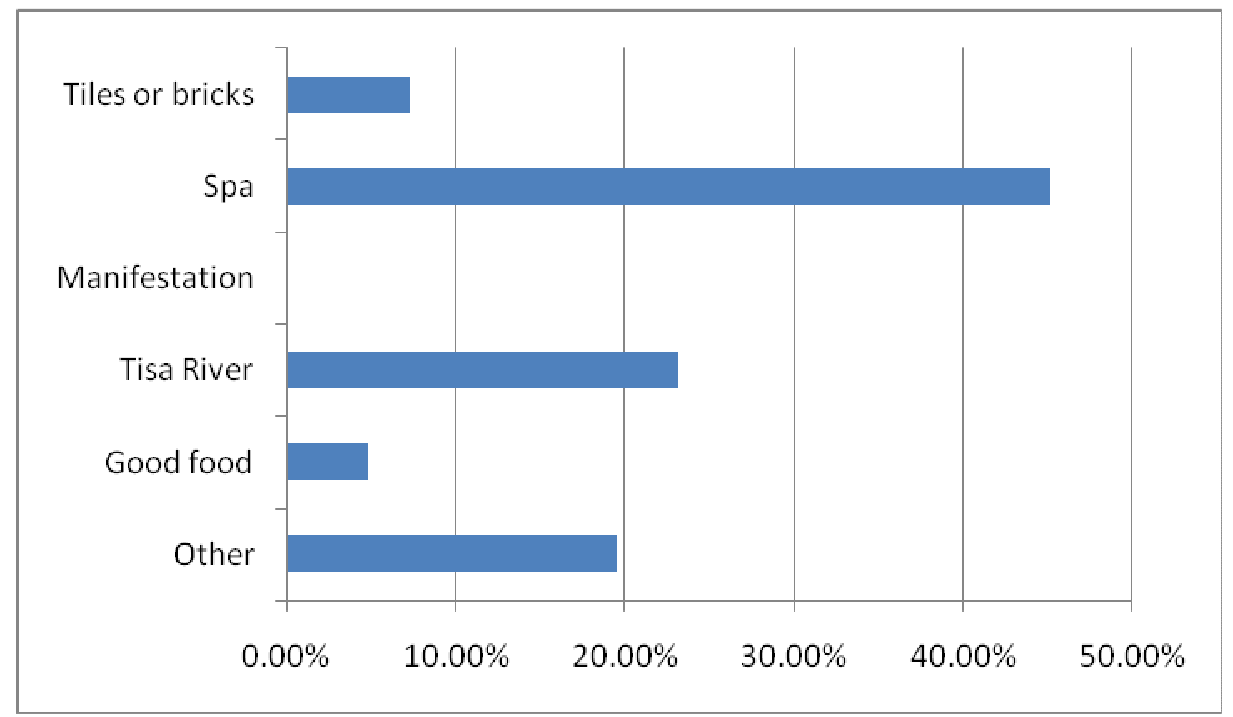

Graphic 1: The Respondents` first Associations with Kanjiza

The multiply answers were defined according to the elements of the tourist offer of Kanjiza, which are used mostly by the promotional activities. The non-tourist associations with Kanjiza marked $7 \%$ of the respondents. The graphic indicates that around half of the respondents answered that the Spa is the first symbol of Kanjiza, which is a tourist characteristic of the town, as well. This result also corresponds with the long tradition of Kanjiza's health tourism. The second important symbol of Kanjiza is the Tisa River and the natural phenomenon of "the blooming Tisa River" $-23 \%$ of the respondents. The category 
"other" cannot be neglected, because it offered a chance to the respondents to write their own thoughts like: sport activities, beautiful nature or a famous artist from Kanjiza, Jozsef Nagy. Although there are a great number of events in Kanjiza and that they are one of the important segment of tourism offer, they are not very significant to the tourist as the first association among the respondents.

Source of information. Many researches indicate that friends and relatives are important sources of information by deciding about tourist destinations, which can be related to the great role of "word of mouth" promotion (Curcic N, 2008). Achieving successful "word of mouth" promotion is not only a matter of a well-planned campaign, but more over of the high level of quality of the tourist products. The source of information appear to be dominated by "Friends and Relatives" with 57\%, indicating a favorable overall impression of Kanjiza. The recommendation comes not only from friends and relatives, but also from doctors, who send their patients on rehabilitation in Kanjiza`s Spa. The number of people getting to know about Kanjiza through the electronic media has increased to $12 \%$ according to this survey. The more important sources of information are shown in the graphic 2:

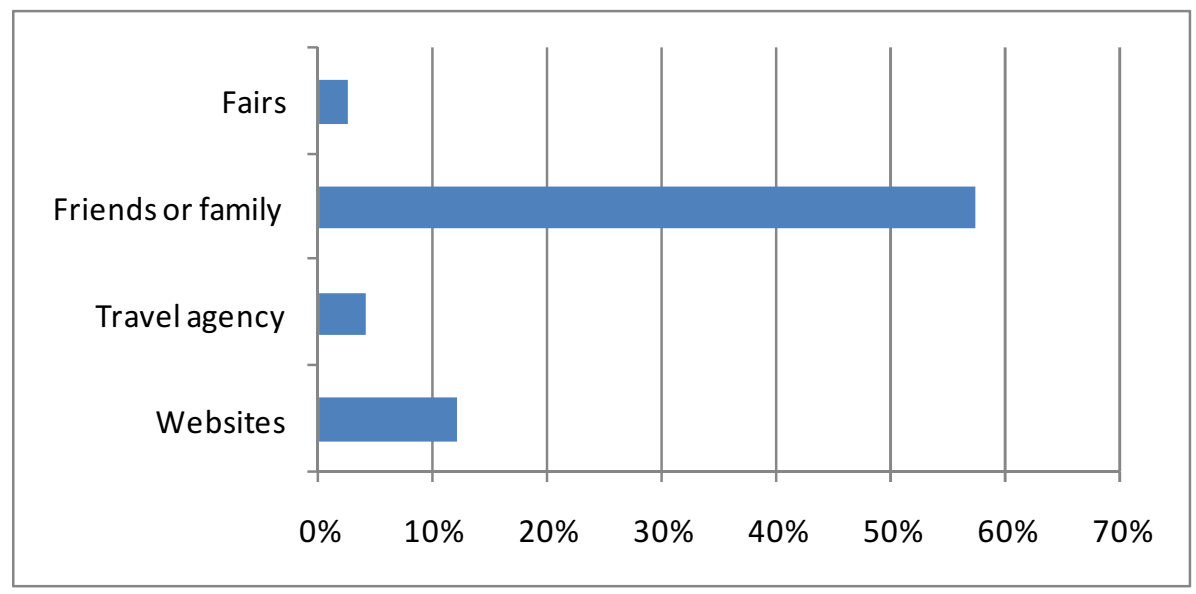

Graphic 2: Sources of Information about Kanjiza

Purpose of visiting Kanjiza. The majority of the respondents $30 \%$ said that the purposes of their stay in Kanjiza are medical reasons, which is related to the first associations of the respondents of Kanjiza. A significant $25 \%$ of the respondents stated relaxation and recreation as the specific purpose of their visit, while only $10 \%$ stated cultural events as the main purpose of the visit (Graphic No. 3). During summer many sport 
events and competitions are organized, which are certainly the reasons for the significance of recreational purposes of visiting Kanjiza.

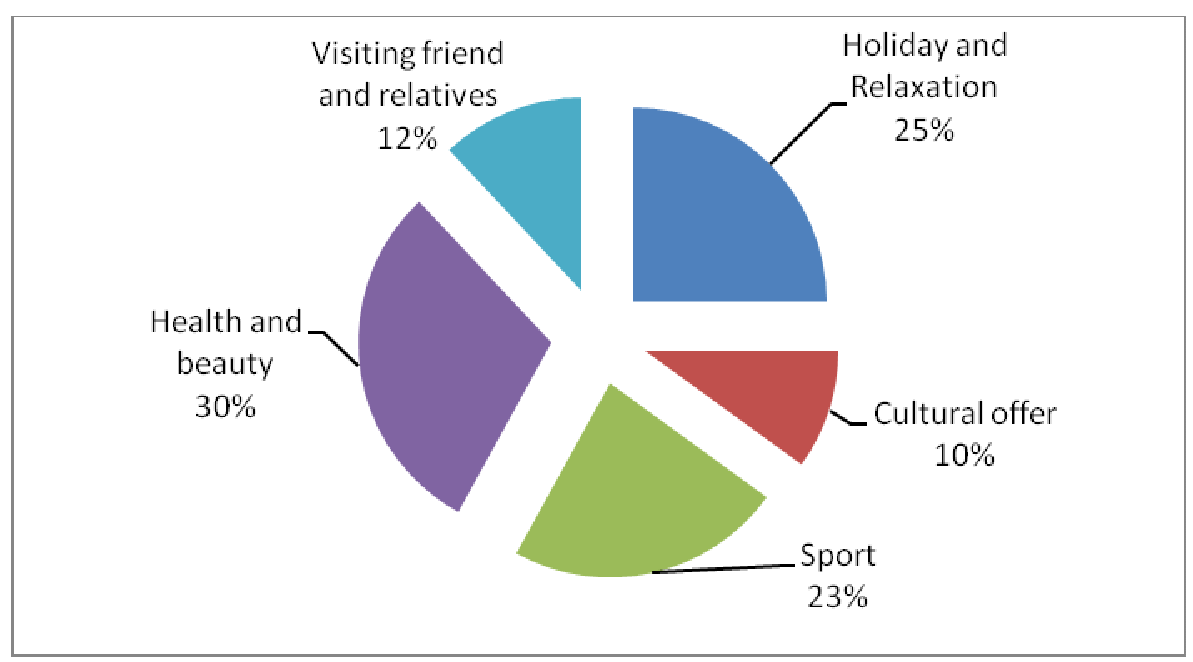

Graphic 3: Purpose of Visiting Kanjiza

Rating of promotional activities. The aim of this question was to determine how the respondents rate those promotional activities, which have influence on the quality of the products and services in tourism.

The products in tourism are so complex, that it is very difficult to be precise in marking the point of affections of the promotional activities. The scheme of tourist destination quality according to French authors can be used for these purposes.

The elements of tourist destination quality from the tourist's point of view are:

- The image of destination before the arrival of the tourist

- Information about the destination before the arrival of the tourist

- Reservation

- The Arrival of the tourist on the tourist destination

- Information obtained during the stay in the tourist destination

- The place of accommodation

- Tourist attractions

- Infrastructure and environment

- The farewell and the way back home

- Contacts and the memories after the holiday. 
According to this scheme, tourists get their impression of a tourist destination through twelve elements of quality. In four of these twelve elements there is the role of promotional activities which are obviously important - the image of destination before the arrival of the tourist, information about the destination before the arrival of the tourist, information obtained during the stay in the tourist destination and contacts and the memories after the holiday. During these four elements of quality, it is of great importance that the representatives of the tourist destination lead creative well-planned promotional campaigns. The analysis about the timing of promotional campaigns indicate that they are essential from the moment of the creation of the potential tourist's needs, wishes and opinions, through the time of the informing and suggesting the decision about the place of holiday, as well as through the time of informing the tourist during their stay to the time after the tourist finishes the holiday, in the place of their residence (Curcic N, 2008).

The respondents rated these elements of promotional activities with grades from 1 "very unsatisfied" to 5 - "very satisfied with this element of promotional activity". The average rating is shown in the Table 1.

\begin{tabular}{|l|c|}
\hline The elements of the promotional activities & Average rating \\
\hline $\begin{array}{l}\text { Information about the destination before the } \\
\text { arrival of the tourist }\end{array}$ & 3,66 \\
\hline $\begin{array}{l}\text { Information obtained during the stay in the } \\
\text { tourist destination }\end{array}$ & 3,61 \\
\hline Tourist signs & 4,33 \\
\hline Souvenirs & 3,16 \\
\hline
\end{tabular}

Table 1: The Average Rating of the Elements of the Promotional Activities, Which Have Impact on the Quality of the Tourist Destination

The lowest average rate was given to the souvenirs in Kanjiza - 3.16. The problem with the souvenirs might lay in their unavailability for the guests of private hotels and other accommodation, because there are too few places in the town where people can buy them open in particular opening hours. The tourist signs were marked the highest by the respondents (4.33). They can be categorized in the group of elements "Information obtained during the stay in the tourist destination".

Accuracy and truthfulness of promotional activities. This qualitative evaluation element of the promotional activities of Kanjiza as a tourist destination was graded by the following question: Does your experience of staying in Kanjiža match your expectations of this town? Over half of the respondents answered that their experience is better than their 
expectation. Very few of respondents stated that their experience was worse and that they are not satisfied with their stay in Kanjiza at all - 4\% (Graphic 4). These results indicate that the promotional activities present the potential visitors of Kanjiza accurately and truthfully the tourist offer.

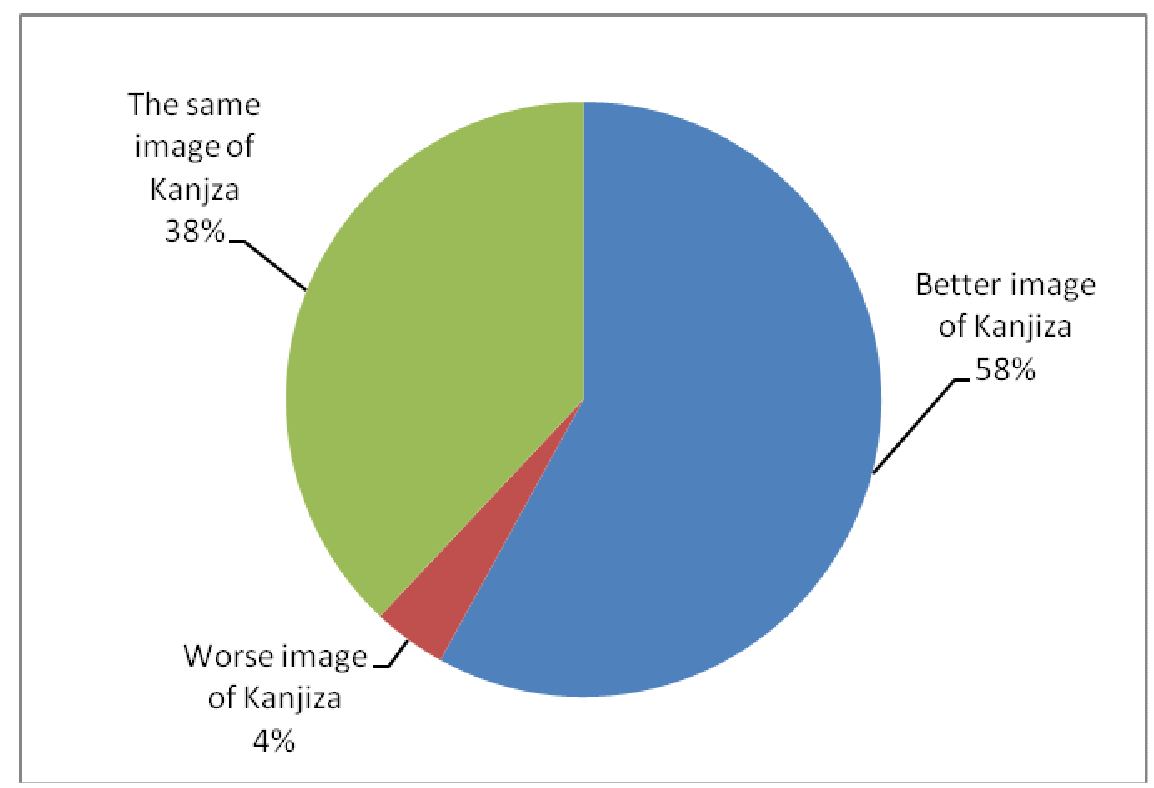

Graphic 4: The Image That the Respondents Gained After Their Stay in Kanjiza

The Respondent's suggestions. In an open-ended question the respondents could write their own ideas to describe the tourist offer in Kanjiza in a way that could be used for promotion. The most frequent answers were: comfort of the accommodation; politeness, professionalism and well organization of the stuff in the rehabilitation centre; efficiency of the rehabilitation programs in Kanjiza (recovery guaranteed 100\%); low prices for foreign tourists and beautiful nature. They also mentioned some segments of the offer that they found interesting for promotion: sport events, Hungarian folklore and cousine, the workshops of Jozef Nagy, recreation facilities. They also found the vicinity of other tourist attractions, such as the Palic Lake, interesting enough to be used in developing the image of Kanjiza as a tourist destination.

\section{CONCLUSION}

Since the beginning of the 20. century, Kanjiza began to develop an image of a rehabilitation and spa centre which eventually led to the growth in tourist arrivals. This research shows that the original image of Kanjiza has not changed ever since the beginning of tourism development in the early 20 . century. 
The influence of friends and relatives recommendation is still the most important factor leading to the increase of the number of the tourists. However, the fact that the percentage of those who gain information through the Internet for the purpose of visiting Kanjiza gradually grows, cannot be ignored. This leeds to the conclusion that the tourism industry in a whole (the Special Hospital for Medical Rehabilitation "Banja Kanjiza", the Tourist Organization of Kanjiza Municipality, private hotels etc.) needs to improve the quality of their internet presentations and to make the purchase of their products and services more available to potential visitors via Internet.

Although the main purpose of visiting Kanjiza is health improvement, the research implies that there are also other purposes which are the result of expanding the tourist offer, such as sport, recreation and events.

The average rating of the elements of promotional activities which have impact on the quality of the tourist destination is mid-ranged, so they should be further improved. That includes information amount and flow between the tourism industry and potential tourists and visitors, as well as the accessibility of souvenirs.

Almost two thirds of the visitors has better image of Kanjiza after their stay and more than a third of them gained experience that mathes their expectations. This leads to a conclusion that the quality of tourism products and services is gradually increasing. Also, the research led to respondents`suggestions about the segments of the tourst offer which could be used in order to attract more visitors.

\section{LITERATURE}

Čerović, S. (2004) Istraživanje tržišta, Prirodno-matematički fakultet, Departman za geografiju, turizam i hotelijerstvo, Novi Sad, p 109.

Čurčić, N. (2008), Kvalitativna ocean sredstava turističke propaganda I primenjenog kartografskog materijala u funkciji unapređenja promotivnih aktivnosti u turizmu, Doktorska disertacija, Prirodno-matematički fakultet, Departman za geografiju, turizam i hotelijestvo, Novi Sad

Mackay, K. - Aramberri, J. and Butler, R. (2005): Picture Worth a Thousand Words? Snapshots from Destination Image Research in Tourism Development: Issues for a Vulnerable Industry, Cromwell Press, p 45

Marvell, A. - Hayward, P. - Reynolds, H. - Stewart, S. (2005): Tourism and Leisure, AS Level for AQA, Heinmann Educational Publishers, Oxford, p 113

Ruane, J. (1998), Essentials of research methods: a Guide to Social Research, Blackwell Publishing, Oxford, p $131-132$ 